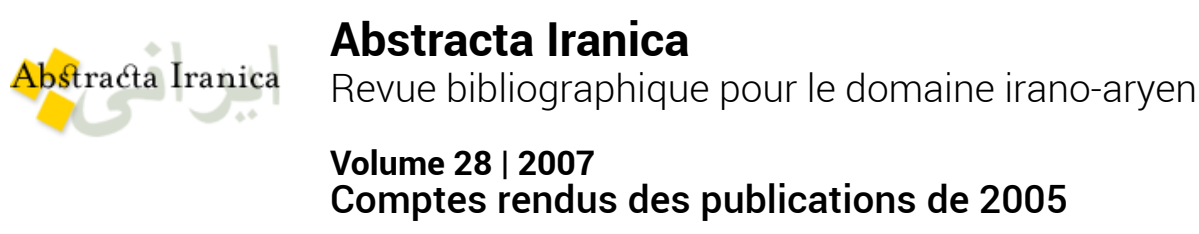

Rendez-vous avec l'islam. Paris, Grasset, 2005, 262 p. Jean-Pierre Digard

(2) OpenEdition

Journals

Édition électronique

URL : http://journals.openedition.org/abstractairanica/18771

DOI : 10.4000/abstractairanica. 18771

ISSN : 1961-960X

Éditeur :

CNRS (UMR 7528 Mondes iraniens et indiens), Éditions de l'IFRI

Édition imprimée

Date de publication : 15 mai 2007

ISSN : 0240-8910

Référence électronique

Jean-Pierre Digard, «Rendez-vous avec l'islam. Paris, Grasset, 2005, 262 p. », Abstracta Iranica [En ligne], Volume 28 | 2007, document 407, mis en ligne le 18 septembre 2007, consulté le 25 septembre 2020. URL : http://journals.openedition.org/abstractairanica/18771 ; DOI : https://doi.org/10.4000/ abstractairanica. 18771

Ce document a été généré automatiquement le 25 septembre 2020.

Tous droits réservés 


\title{
Rendez-vous avec l'islam. Paris, Grasset, 2005, 262 p.
}

\author{
Jean-Pierre Digard
}

Journaliste, éditorialiste au Figaro, l'A. a sur l'islam des idées qui détonent. Non pour leur point de départ, outrancier et, hélas, largement partagé - «l'islamisme est un fascisme »-, mais pour les « solutions » qu'il propose. Pour lui, le vrai danger est l'islam sunnite, islam des Frères musulmans, d'Al-Qaida et du salafisme. Pour endiguer et réformer cet islam sunnite, il place ses espoirs dans la Turquie moderniste, pourtant très majoritairement sunnite, et, ce qui est plus inhabituel, sur l'Iran de la République islamique, en dépit de son radicalisme. C'est qu'Adler voit dans le chi'isme une religion de dissidents et de minoritaires, qui a donné, au cours de l'histoire, maints gages de sa tolérance et de son ouverture. On ne saurait trouver exemple plus patent et plus caricatural d'« essentialisme »!

\section{INDEX}

Thèmes : 13.1. Iran

\section{AUTEURS}

JEAN-PIERRE DIGARD

CNRS / Mondes iranien et indien - Paris 